\title{
KORBAN ALIH FUNGSI LAHAN DI KELURAHAN SETIANAGARA, KECAMATAN CIBEUREUM, KOTA TASIKMALAYA, JAWA BARAT
}

\author{
VICTIMS OF LAND USE CONVERSION INSETIANAGARA, \\ CIBEUREUM DISTRICT, TASIKMALAYA CITY, WEST JAVA
}

\author{
Ivanka Marayandini*, Trisna Insan Noor \\ Program Studi Agribisnis, Fakultas Pertanian, Universitas Padjadjaran \\ *Email: ivanka.marayan@gmail.com \\ (Diterima 08-04-2020; Disetujui 08-06-2020)
}

\begin{abstract}
ABSTRAK
Kecamatan Cibeureum merupakan salah satu dari empat kecamatan di Kota Tasikmalaya dengan pengurangan luas lahan sawah paling tinggi. Penelitian dilakukan di Kelurahan Setianagara yang termasuk wilayah LP2B (Lahan Pertanian Pangan Berkelanjutan), namun masih mengalami alih fungsi lahan. Penelitian ini bertujuan untuk mengetahui profil korban alih fungsi lahan, faktor pendorong dan penarik korban beralih fungsi lahan, dan keadaan korban sebelum dan sesudah alih fungsi lahan. Desain pada penelitian ini menggunakan desain deskriptif kualitatif dan teknik penelitiannya menggunakan studi kasus. Informasi yang diperoleh berasal dari hasil wawancara dan observasi. Informan dalam penelitian ini merupakan korban alih fungsi lahan. Hasil penelitian menunjukkan bahwa faktor pendorong alih fungsi lahan berasal dari diri sendiri dan paksaan, sedangkan faktor penariknya berasal dari pembeli lahan sawah tersebut dan paksaan. Keadaan petani sebelum dan sesudah alih fungsi lahan berubah menjadi lebih buruk, tetap, dan lebih baik.
\end{abstract}

Kata kunci: Korban, Alih Fungsi Lahan

\section{ABSTRACT}

Cibeureum District is one of the four sub-districts in the City of Tasikmalaya with the highest reduction in paddy fields area. The study was conducted in Setianagara which is included in the $L P 2 B$ (Sustainable Food Agricultural Land) area but is still experiencing lang conversion. This study aims to determine the profile of victims of land use change, push and pull factors switching land use, and the condition of the victims before and after land use change. The design in this study used a qualitative descriptive design and research techniques using case studies. The information obtained comes from interviews and observations. Informants in this study are victims of land use change. The results showed that the factors driving the conversion of land originated from self and coercion, while the pull factors came from the buyers of the paddy fields and coercion. The situation of farmers before and after land use change has changed for the worse, more stable, and better.

Keywords: Victims, Land Use Conversion

\section{PENDAHULUAN}

Indonesia merupakan negara agraris yang kaya akan sumber daya alam. Sebagian besar penduduk Indonesia bekerja di sektor pertanian sehingga menggantungkan hidupnya pada lahan pertanian. Salah satu lahan pertanian di Indonesia adalah lahan sawah yang mampu menghasilkan padi. Padi adalah komoditas pangan strategis nasional dan memiliki sensitivitas yang tinggi ditinjau dari aspek politis, ekonomi, dan 
kerawanan sosial. Beras yang merupakan hasil pengolahan padi adalah makanan pokok bagi masyarakat Indonesia. Hal tersebut menjadikan beras sebagai kebutuhan pokok hingga membuat kebutuhan masyarakat akan beras menjadi tinggi yang ditunjukkan dengan tingkat konsumsi beras nasional yang mencapai 124,89 kg/kapita/tahun (BPS, 2017). Lebih dari 95\% beras dihasilkan dari lahan sawah (Swastika et al, 2007). Hal tersebut mengimplikasikan pentingnya lahan sawah dalam pemenuhan kebutuhan beras di masyarakat. Maka dari itu, lahan tidak hanya memiliki nilai ekonomis, tetapi juga nilai sosial dan nilai religious (UU RI No. 41 Tahun 2009).

Jumlah luas lahan yang ada tidak sebanding dengan meningkatnya jumlah penduduk dan kebutuhan masyarakat. Peningkatan jumlah penduduk menunjukkan bahwa kebutuhan akan perumahan, pertokoan, pasar, dan lainlain, ikut meningkat dan menggeser lahan pertanian dengan merubah jenis penggunaan lahan pertanian ke non pertanian atau dapat disebut alih fungsi lahan. Alih fungsi lahan didefinisikan sebagai perubahan fungsi sebagian atau seluruh kawasan lahan dari fungsinya semula menjadi fungsi lain yang membawa masalah terhadap lingkungan dan potensi lahan itu sendiri.

Alih fungsi lahan pertanian produktif yang terbesar di Indonesia adalah di Jawa Barat (Surono, 2016). Angka pembangunan di Jawa Barat merupakan yang tertinggi di Indonesia dan lahan yang digunakan untuk pembangunan adalah lahan pertanian produktif. Lahan pertanian di Jawa Barat dominan dengan lahan sawah, dan luas lahan sawah di Jawa Barat ditunjukkan pada Gambar 1.

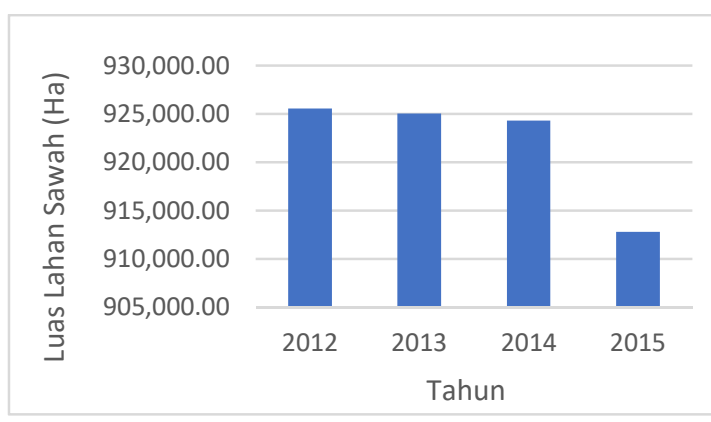

Gambar 1. Luas Lahan Sawah Provisi Jawa Barat, 2012-2015 (Sumber: Badan Pusat Statistik, 2017)

Gambar 1 menunjukkan bahwa luas lahan sawah di Jawa Barat terus mengalami penurunan dari tahun ke tahun. Alih fungsi lahan dapat berpengaruh pada penurunan produksi padi sehingga mengancam ketahanan pangan. Selain itu, alih fungsi lahan juga menyebabkan makin sempitnya luas lahan yang diusahakan dan sering berdampak pada menurunnya tingkat kesejahteraan petani. Oleh sebab itu, diperlukannya pengendalian alih fungsi 
lahan khususnya lahan sawah melalui perlindungan lahan pertanian pangan untuk mewujudkan ketahanan pangan, kedaulatan pangan, meningkatkan kemakmuran, dan kesejahteraan petani dan masyarakat yang tercantum dalam kebijakan.

Salah satu kebijakan yang dimaksud yaitu UU RI Nomor 41 Tahun 2009 Tentang Perlindungan Lahan Pertanian Pangan Berkelanjutan (LP2B). Perlindungan LP2B adalah sistem dan proses dalam merencanakan dan menetapkan, mengembangkan, memanfaatkan dan membina, mengendalikan, dan mngawasi lahan pertanian pangan dan kawasannya secara berkelanjutan (UU RI No. 41 Tahun 2009). Sedangkan pengertian dari LP2B itu sendiri adalah bidang lahan pertanian yang ditetapkan untuk dilindungi dan dikembangkan secara konsisten guna menghasilkan pangan pokok bagi kemandirian, ketahanan, dan kedaulatan pangan nasional (UU RI No. 41 Tahun 2009). Lahan yang dijadikan sebagai LP2B berada pada kawasan perdesaan dan/atau pada kawasan perkotaan di wilayah kabupaten/kota (UU RI No. 41, Pasal 7 Tahun 2009).

Salah satu daerah di Jawa Barat yang telah menerapkan kebijakan LP2B yaitu Kota Tasikmalaya. Kebijakan tersebut ada pada Peraturan Daerah Kota Tasikmalaya Nomor 4 Tahun 2012 paragraf 7 Pasal 49 ayat 2, Tentang Rencana Tata Ruang Wilayah (RTRW) Tahun 2011 - 2031. Kota Tasikmalaya sendiri merupakan kota dengan luas panen padi sawahnya paling tinggi di Provinsi Jawa Barat yaitu 66.399 ton dengan rata-rata produksi $51,56 \mathrm{kw} / \mathrm{Ha}$ (BPS Provinsi Jawa Barat, 2015). Namun sayangnya Kota Tasikmalaya masih mengalami alih fungsi lahan dengan melihat dari luas lahan sawah yang terus menurun setiap tahunnya ditunjukkan pada Gambar 2.

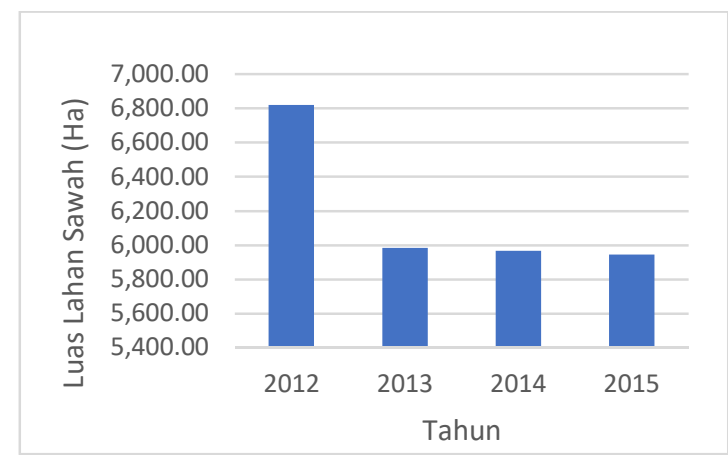

Gambar 2. Luas Lahan Sawah Kota Tasikmalaya, 2012-2015 (Sumber: Badan Pusat Statistik, 2017)

Tidak semua kecamatan di Kota Tasikmalaya termasuk ke dalam LP2B, melainkan hanya 4 Kecamatan yang meliputi area seluas 492 ha, yaitu Kecamatan Cibeureum, Kawalu, Mangkubumi, dan Purbaratu berdasarkan Perda Nomor 4 Tahun 2012. Selain itu, tidak semua kelurahan pada keempat 
Kecamatan tersebut merupakan lahan LP2B. Hanya di Kecamatan Cibeureum dan Purbaratu yang seluruh kelurahannya ditetapkan sebagai lahan LP2B. Sedangkan Kecamatan Kawalu dan Mangkubumi hanya sebagian kelurahannya yang ditetapkan sebagai lahan LP2B.

Meskipun LP2B sudah ditetapkan, 2 dari 4 Kecamatan tersebut masih mengalami alih fungsi lahan yang ditunjukkan pada Tabel 1.

Tabel 1. Perkembangan Luas Lahan Baku Sawah di Kota Tasikmalaya Tahun 2013 - 2016

\begin{tabular}{lccccc}
\hline \multicolumn{1}{c}{ Kecamatan } & $\mathbf{2 0 1 3}$ & $\mathbf{2 0 1 4}$ & $\mathbf{2 0 1 5}$ & $\mathbf{2 0 1 6}$ & $\begin{array}{c}\text { Luas Pengurangan } \\
\text { Lahan (Ha) }\end{array}$ \\
& $\mathbf{( H a )}$ & $\mathbf{( H a )}$ & $\mathbf{( H a )}$ & $\mathbf{( H a )}$ & - \\
Kawalu & 1.244 & 1.244 & 1.244 & 1.244 & $\mathbf{5}$ \\
Cibeureum & $\mathbf{7 6 3 , 5}$ & $\mathbf{7 6 3 , 5}$ & $\mathbf{7 6 3 , 5}$ & $\mathbf{7 5 8 , 5}$ & - \\
Purbaratu & 499 & 499 & 499 & 499 & 2 \\
Mangkubumi & 1.134 & 1.134 & 1.134 & 1.132 &
\end{tabular}

Berdasarkan Tabel 1, Kecamatan

Cibeureum menduduki peringkat pertama dengan luas pengurangan lahan tertinggi yaitu hingga 5 ha. Pengurangan luas lahan tersebut ditunjukkan pada tahun 2015 ke tahun 2016. Hal tersebut terjadi karena Kecamatan Cibeureum berlokasi dekat dengan pusat kota, sehingga pembangunannya terus berkembang ke arah perkotaan.

Salah satu kelurahan di Kecamatan Cibeureum yang ditetapkan sebagai lahan LP2B adalah Kelurahan Setianagara dengan total luas lahan 50 ha (BPS Kecamatan Cibeureum Dalam Angka Tahun 2017). Meski sudah termasuk lahan LP2B, Kelurahan Setianagara masih mengalami penyimpangan yang ditunjukkan dengan pembangunan pesantren terpadu dan Sekolah Tinggi Ilmu Adab dan Budaya Islam (STIABI) pada tahun 2018 hingga tahun 2019. Selain itu, lokasinya yang cukup dekat dengan pusat Kota Tasikmalaya. Kelurahan Setianagara menuju pusat Kota Tasikmalaya yaitu Alun-Alun Kota Tasikmalaya hanya berjarak $5 \mathrm{~km}$. Oleh karena itu, banyak lahan sawah yang teralih fungsikan.

Alih fungsi lahan yang terjadi di Kelurahan Setianagara lambat laun akan memberi dampak kepada petani, yaitu mempengaruhi kegiatan usahataninya dan keberlangsungan hidup petani. Dikhawatirkan semakin banyaknya petani yang melakukan alih fungsi lahan atau melepas lahan miliknya akan mempengaruhi jumlah luas lahan di Kelurahan tersebut.

Berdasarakan fenomena di atas, maka peneliti tertarik untuk mengkaji lebih lanjut tentang korban alih fungsi 
lahan di Kelurahan Setianagara, Kecamatan Cibeureum, Kota Tasikmalaya, Jawa Barat.

\section{METODE PENELITIAN}

Penelitian ini menggunakan desain kualitatif dengan metode studi kasus. Dalam penentuan tempat penelitian menggunakan teknik purposive dan dalam menentukan informan di lapangan menggunakan Snow Ball Technique. Jumlah informan yang didapat dalam penelitian mengenai korban alih fungsi lahan di Kelurahan Setianagara, Kecamatan Cibeureum, Kota Tasikmalaya, Jawa Barat yaitu sebanyak 3 informan.

Sumber data berasal dari data primer dan data sekunder. Data primer diperoleh dari hasil pengamatan dan wawancara langsung, sedangkan data sekunder diperoleh dari informan pihak terkait dan sumber pustaka.

\section{HASIL DAN PEMBAHASAN}

Kelurahan Setianagara berada di Kecamatan Cibeureum, Kota Tasikmalaya, Jawa Barat dengan luas sebesar 131,50 ha. Batas wilayah Kelurahan Setiangara sebelah utara berbatasan dengan Kelurahan Purbaratu, Kecamatan Purbaratu, sebelah timur berbatasan dengan Kelurahan Kotabaru, Kecamatan Cibeureum, sebelah selatan berbatasan dengan Kelurahan Kotabaru, Kecamatan Cibeureum, dan sebelah barat berbatasan dengan Kelurahan Sukanagara, Kecamatan Purbaratu.

Kelurahan Setianagara terdiri atas 7 RW dan 20 RT dengan jumlah kepala keluarga $1.487 \mathrm{KK}$. Jumlah penduduk sebanyak 4.697 orang yang didominasi oleh kelompok umur 15-64 tahun.

Sarana pendidikan di Kelurahan Setianagara berjumlah 12 yang terdiri atas PAUD hingga SMA. Rata-rata tingkat pendidikan penduduk adalah tamat SD. Masyarakat di Kelurahan Setianagara memilik mata pencaharian yang beragam jenisnya dan rata-rata masyarakat bermata pencaharian sebagai buruh.

Sebagian besar lahan di Kelurahan Setiangara digunakan sebagai lahan sawah dan ladang dengan luas lahan sawah sebesar 50 ha. Jenis sawah di Kelurahan Setianagara yaitu sawah irigasi teknis dengan sumber air dari Sungai Cimulu dan Sungai Ciherang. Jumlah petani sebanyak 282 orang yang tergabung dalam 3 kelompok tani.

\section{Korban Alih Fungsi Lahan}

Informan dalam penelitian ini adalah petani korban alih fungsi lahan 
sawah di Kelurahan Setianagara, Kecamatan Cibeureum, Kota Tasikmalaya, Jawa Barat. Petani yang dimaksud adalah baik petani pemilik maupun petani penggarap. Jumlah informan yang berhasil peneliti temui sebanyak 3 orang, yaitu informan A, B, dan C.

Informan A merupakan petani penggarap yang lokasi garapannya berada di Desa Warung Bandung. Lahan garapan dan tempat tinggal memiliki lokasi yang berbeda, dimana tempat tinggal berada di Desa Purbaratu bersama dengan istri dan 1 anaknya yang masih sekolah.

Informan B merupakan petani pemilik yang berasal dari Pagarsih, Bandung. Beliau merantau ke Desa Leuwigenta, Tasikmalaya untuk mencari pekerjaan dan menetap setelah menikah dengan pasangannya yang berasal dari Tasikmalaya. Tinggal bersama dengan istri dan ketiga anaknya, dimana dua diantaranya masih sekolah. Selain menjadi kepala keluarga, informan B juga merupakan Kepala RW 06 Leuwigenta yang baru menjabat 2 tahun lalu.

Informan C merupakan petani pemilik dan penggarap sekaligus Ketua Kelompok Tani Genta Riksa yang beranggotakan 69 orang petani. Tinggal di Desa Leuwigenta bersama dengan istri dan kedua anaknya, dimana salah satu diantaranya masih menempuh pendidikan di Universitas Siliwangi. Istri informan bekerja sebagai seorang guru, sedangkan informannya sendiri merupakan seorang pensiunan guru.

Karakteristik yang dimiliki setiap petani berbeda-beda antara satu dengan yang lainnya. Karakteristik informan ditunjukkan dengan beberapa indikator yaitu umur, tingkat pendidikan, pekerjaan, status penguasaan lahan, pengalaman usahatani, luas lahan, dan modal usahatani yang ditunjukkan pada Tabel 2.

Tabel 2. Karakteristik Informan

\begin{tabular}{|c|c|c|c|}
\hline \multirow{2}{*}{ Indikator } & \multicolumn{3}{|c|}{ Informan } \\
\hline & $\mathbf{A}$ & B & $\mathrm{C}$ \\
\hline Umur & 60 tahun & 45 tahun & 70 tahun \\
\hline Tingkat Pendidikan & SD & SMA & SD \\
\hline Pekerjaan & Petani & $\begin{array}{c}\text { Mebel Kayu (Setengah } \\
\text { jadi) }\end{array}$ & Petani \\
\hline Status Penguasaan Lahan & Penggarap & Pemilik & $\begin{array}{l}\text { Pemilik dan } \\
\text { Penggarap }\end{array}$ \\
\hline Pengalaman Usahatani & 45 tahun & 20 tahun & 45 tahun \\
\hline Lahan Dijual & 0,448 ha & 0,14 ha & 0,028 ha \\
\hline Lahan Saat Ini & 0,042 ha & 0,28 ha & 0,616 ha \\
\hline Modal Usahatani & Rp 500.000 & Rp 175.000 & Rp 1.500.000 \\
\hline
\end{tabular}

Sumber: Analisis Data, 2020 
Faktor Pendorong dan Penarik Alih Fungsi Lahan

Faktor-faktor yang mempengaruhi alih fungsi lahan pertanian dapat dibedakan menjadi dua, yaitu faktor langsung dan tak langsung. Faktor langsung serupa dengan faktor pendorong yaitu faktor alih fungsi di tingkat petani dimana faktor tersebut mempengaruhi langsung keputusan petani seperti kondisi sosial ekonomi petani, pendidikan, pendapatan, kemampuan secara ekonomi, pajak tanah, harga tanah, dan lokasi tanah. Faktor tak langsung yaitu faktor alih fungsi yang tidak secara langsung mempengaruhi keputusan petani dan serupa dengan faktor penarik seperti meningkatnya pertumbuhan penduduk yang berpengaruh terhadap pertumbuhan pembangunan sehingga meningkatnya permintaan akan lahan.

Faktor pendorong alih fungsi lahan informan A yaitu keadaan ekonomi pemilik lahan garapan informan yang membutuhkan biaya untuk pendidikan kedua anaknya sehingga dorongan tersebut berasal dari diri sendiri. Sedangkan faktor penariknya yaitu adanya pembeli yang memiliki minat untuk membeli lahan sawah tersebut karena melihat lokasi lahan yang strategis membuat pemilik lahan semakin yakin untuk menjual lahan sawah miliknya.

Faktor pendorong alih fungsi lahan informan $\mathrm{B}$ adalah dari dalam diri informan sendiri karena membutuhkan biaya untuk pendidikan anaknya. Sedangkan faktor penariknya adalah sekolah terpadu yang berniat untuk membeli lahan sawah milik informan hingga pada akhirnya informan menjual lahan sawah tersebut.

Berbeda halnya dengan informan A dan B, faktor pendorong dan penarik informan $\mathrm{C}$ adalah karena sudah merasa tidak nyaman akan dampak dari pembangunan sekolah terpadu. Ketidaknyamanan tersebut dimulai dari sampah yang berjatuhan hingga akses menuju lahan sawah terhalang. Oleh sebab itu, pemilik lahan akhirnya menjual lahan sawah tersebut.

\section{Keadaan Sebelum dan Setelah Alih Fungsi Lahan}

Keadaan petani dari sebelum dan setelah alih fungsi lahan dapat terjadi perubahan. Antara petani satu dengan petani lain akan berbeda pula keadaannya. Perbedaan tersebut merupakan akibat dari alih fungsi lahan dengan melihat beberapa indikator. 
Indikator-indikator tersebut terdiri atas pekerjaan sesudah alih fungsi lahan, anggota keluarga yang bekerja, pemanfaatan konpensasi dari menjual lahan sawah, pengeluaran dan pendapatan sebelum dan sesudah alih fungsi lahan.

Keadaan dapat menjadi lebih baik dari keadaan sebelumnya, tetap seperti keadaan sebelumnya, atau semakin buruk dibanding keadaan sebelumnya. Indikator-indikator keadaan petani yang menjadi informan dalam penelitian ini ditunjukkan pada Tabel 3.

Tabel 3. Indikator Pendukung Keadaan Petani

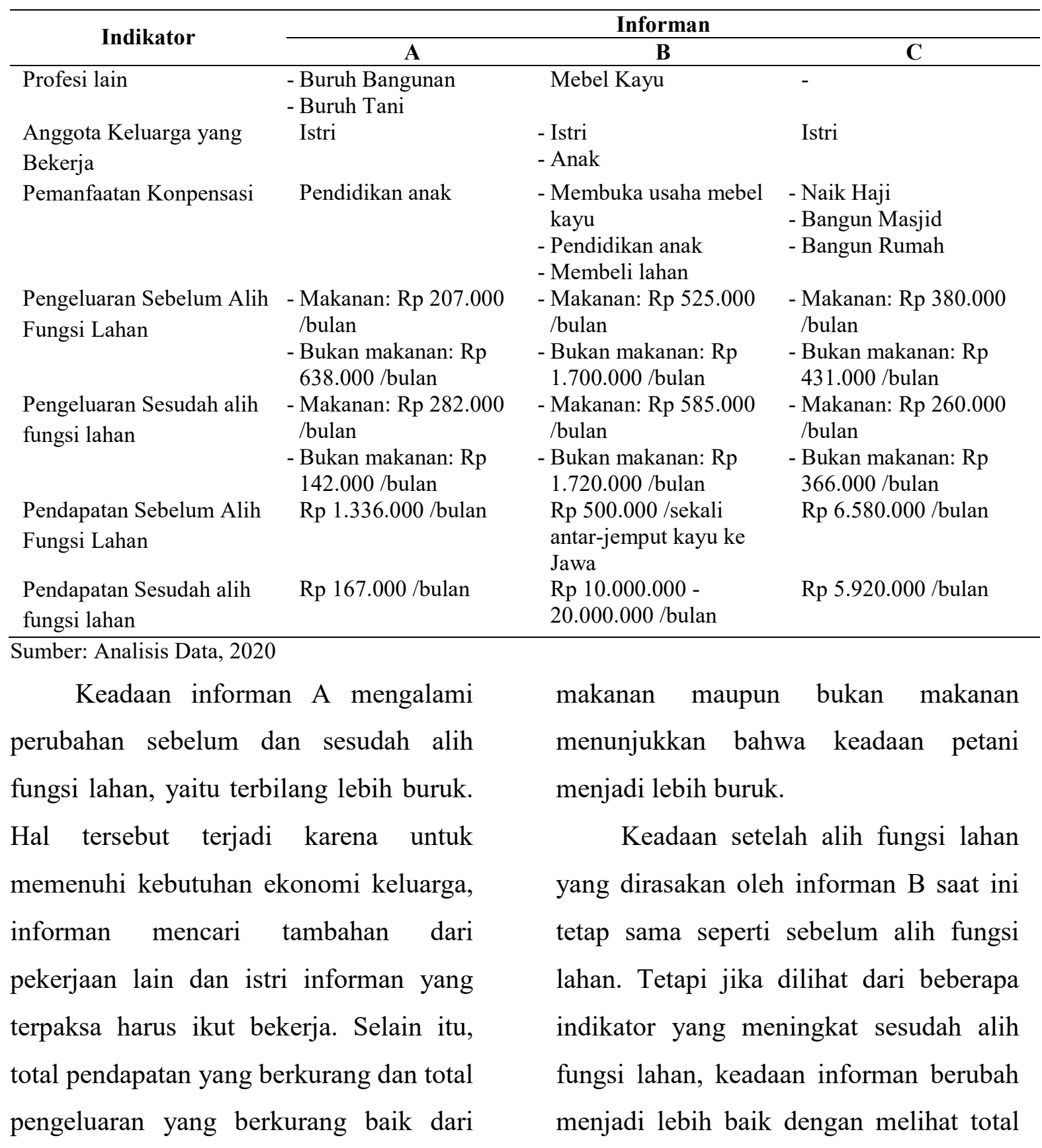


pendapatan yang meningkat. Selain informan B yang memenuhi kebutuhan ekonomi keluarga, istri informan juga bekerja sebagai supplier baju untuk saudaranya yang berjualan baju keliling dan anak informan membuka bengkel motor yang bernama NES 37 Project. Bengkel motor tersebut khusus untuk repaint dan carbon, modif kontes dan harian, dan striping transparan dan biasa.

Berbeda halnya dengan informan A dan B yang mengalami perubahan, keadaan informan $\mathrm{C}$ sesudah alih fungsi lahan justru terbilang tetap dibanding sebelumnya meskipun total pendapatan berkurang. Hal tersebut terjadi karena pendapatan setelah alih fungsi lahan masih cukup untuk menghidupi keluarga dan membiayai anak terakhir yang masih sekolah di perguruan tinggi. Terlebih lagi, istri informan yang bekerja sebagai guru sekolah ikut membantu perekonomian dalam keluarganya. Jika dilihat dari luas lahan sawah informan $\mathrm{C}$ yang berkurang hanya sebagian kecil dari luas lahan yang dimiliki dan digarapnya. Luas lahan sawah garapannya sebelum dan sesudah alih fungsi lahan masih termasuk ke dalam kategori sedang.

\section{KESIMPULAN}

Berdasarkan hasil penelitian dapat ditarik kesimpulan sebagai berikut:

1. Petani di Kelurahan Setianagara yaitu informan A dan B menjual lahan sawah dengan faktor pendorong dari diri sendiri secara sadar dan faktor penariknya adalah adanya pembeli lahan sawah tersebut. Sedangkan, informan $\mathrm{C}$ menjual lahan sawah dengan faktor pendorong dan penariknya yaitu paksaan dari pihak luar yang ingin membeli lahan sawah garapannya.

2. Keadaan informan sebelum dan sesudah alih fungsi lahan bergantung pada status penguasaan lahan dan luas lahan sawah yang digarap sesudah alih fungsi lahan. Sempit, sedang atau luasnya lahan akan berpengaruh terhadap total pendapatan dan pengeluaran. Semakin sempit lahan yang dimiliki ataupun digarap maka semakin sedikit pendapatan yang didapat setiap bulannya, sedangkan lahan yang lebih luas atau sedang memiliki pendapatan yang lebih banyak dibanding lahan yang sempit. Dilihat dari perubahan keadaan pada setiap informan yang terjadi, maka yang menjadi korban alih fungsi lahan 
di Kelurahan Setianagara hanya informan A.

\section{DAFTAR PUSTAKA}

Badan Pusat Statistik Kota Tasikmalaya. (2018). Kecamatan Cibeureum Dalam Angka 2018. Tasikmalaya: Badan Pusat Statistik Kota Tasikmalaya.

BPS. (2017). Provinsi Jawa Barat dalam angka 2011-2016. Jawa Barat: Badan Pusat Statistik Jawa Barat.

Dinaryanti, N. (2014). Faktor-Faktor Yang Mempengaruhi Alih Fungsi Lahan Pertanian di Daerah Sepanjang Irigasi Bendung Colo Kabupaten Sukoharjo. Tesis. Fakultas Ekonomi dan Bisnis Universitas Diponegoro. Semarang.

Dinas Pertanian. (2017). Rancangan Revisi RTRW Kota Tasikmalaya. Kota Tasikmalaya: Dinas Pertanian Bidang Pangan.
Hafidah, N, et. Al. (2017). Dampak Alih Fungsi Lahan Pertanian Terhadap Perlindungan Hak Masyarakat Atas Pangan Studi Di Kabupaten Banjar. Badamai Law Journal, 2(1): 173186.

Munir, M. (2008). Pengaruh Konversi Lahan Pertanian Terhadap Tingkat Kesejahteraan Rumah Tangga Petani (Kasus Desa Candimulyo, Kecamatan Kertek, Kabupaten Wonosobo, Provinsi Jawa Tengah). Skripsi. Program Studi Komunikasi dan Pengembangan Masyarakat Fakultas Pertanian IPB. Bogor.

Perda Kota Tasikmalaya Nomor 4 Tahun 2012 paragraf 7 Pasal 49 Ayat 2 RTRW Tahun 2011-2031.

UU RI No 41 Tahun 2009 Tentang Perlindungan Lahan Pertanian Pangan Berkelanjutan. Departemen Pertanian. Provinsi Jawa Barat Dalam Angka 2011-2015. 